\title{
Behavioral Evidence for Interactions between a Hallucinogenic Drug and Group II Metabotropic Glutamate Receptors
}

Jonathan C. Gewirtz, Ph.D., and Gerard J. Marek, M.D., Ph.D.

Recent electrophysiological studies in our laboratory have demonstrated a physiological interaction between $5-\mathrm{HT}_{2 A}$ and metabotropic glutamate $2 / 3$ ( $m G l u 2 / 3)$ receptors in the medial prefrontal cortex. Several behavioral studies have found that phenethylamine hallucinogens with partial agonist activity at $5-H T_{2 A}$ receptors induce head shakes when directly administered into the medial prefrontal cortex. The purpose of the present experiments was to examine whether an interaction occurs between $m G l u 2 / 3$ and $5-H T_{2 A}$ receptors on a behavioral level using head shakes induced by phenethylamine hallucinogens as a model of $5-H T_{2 A}$ receptor activation. Administration of the mGlu2/3 agonist LY354740 (0.3-10 $m g / k g$, ip) suppressed head shakes induced by the phenethylamine hallucinogen 1-(2,5-dimethoxy-4iodophenyl)-2-aminopropane (DOI). Conversely, administration of the $\mathrm{mGlu2/3}$ antagonist LY341495 (1 mg/ $\mathrm{kg}$, ip) enhanced the frequency of DOI-induced head shakes. Taken together, these results raise the possibility that the psychomimetic properties of hallucinogenic drugs may be mediated in part, via increased glutamate release following activation of $5-\mathrm{HT}_{2 \mathrm{~A}}$ receptors.

[Neuropsychopharmacology 23:569-576, 2000] (C) 2000 American College of Neuropsychopharmacology. Published by Elsevier Science Inc.
KEY WORDS: Phenethylamines; Hallucinogens; Serotonin; $m G l u 2 / 3$ receptors; Head shakes; DOI; $5-H_{2 A}$ receptors; LY354740

Activation of 5-hydroxytryptamine $2 \mathrm{~A}\left(5-\mathrm{HT}_{2 \mathrm{~A}}\right)$ receptors is thought to mediate many effects of ergoline (e.g., lysergic acid diethylamide; LSD), simple indoleamine (e.g., psilocybin), and phenethylamine (e.g., 1-(2,5dimethoxy-4-iodophenyl)-2-aminopropane; DOI) hallucinogens in both rodents and humans (Glennon 1990; Marek and Aghajanian 1996; Titeler et al. 1988; Vollenweider et al. 1998). The administration of the $5-\mathrm{HT}_{2 \mathrm{~A} / \mathrm{B} / \mathrm{C}}$

From the Department of Psychiatry, Yale School of Medicine, Connecticut Mental Health Center, and the Ribicoff Research Facilities, Rm. 335d, 34 Park Street, New Haven, CT 06508.

Address correspondence to: Gerard J. Marek, M.D., Ph.D., Yale School of Medicine, Connecticut Mental Health Center, and the Ribicoff Research Facilities, Rm. 335d, 34 Park Street, New Haven, CT 06508; Tel.: 203-974-7763; Fax: 203-974-7897; E-mail: Gerard.Marek @Yale.edu

Received February 10, 2000; revised April 7, 2000; accepted April $25,2000$. agonist DOI to rats elicits a constellation of behavioral and physiological effects including head shakes or headtwitches, skin jerks, forepaw treading, rearing, chewing, changes in locomotor activity, hyperthermia and neophobia (Gudelsky et al. 1986; Pranzatelli 1990; Wing et al. 1990). The head shakes induced by 5 -HT agonists can be blocked by non-selective $5-\mathrm{HT}_{2}$ antagonists (Colpaert and Janssen 1983; Lucki et al. 1984; Peroutka et al. 1981; Yap and Taylor 1983). Moreover, studies employing antagonists selective for $5-\mathrm{HT}_{2 \mathrm{~A}}$ or $5-\mathrm{HT}_{2 \mathrm{C}}$ receptors have shown that head shakes induced by DOI are mediated via activation of $5-\mathrm{HT}_{2 \mathrm{~A}}$ receptors (Schreiber et al. 1995; Willins and Meltzer 1997). Recent work similarly finds that DOI and other hallucinogenic drugs fail to induce head twitches when administered to $5-\mathrm{HT}_{2 \mathrm{~A}}$ receptor knockout mice, in contrast to wild-type mice (Gingrich et al. 1999). Thus, DOI-induced head shakes have become the most widely used behavioral model for the study of $5-\mathrm{HT}_{2 \mathrm{~A}}$ receptors in rodents.

It has been reported that local infusion of $1-(2,5-$ dimethoxyphenyl-4-bromo)-2-aminopropane (DOB) and 
DOI into the medial prefrontal cortex induces head shakes (Granhoff et al. 1992a; Willins and Meltzer 1997). 5-HT $2 \mathrm{~A}$ receptors appear to be prominently expressed on the apical dendrites of pyramidal cells in the neocortex (Jakab and Goldman-Rakic 1998; Willins et al. 1997). In addition to activation of postsynaptic $5-\mathrm{HT}_{2 \mathrm{~A}}$ receptors on these pyramidal cells, 5- $\mathrm{HT}_{2 \mathrm{~A}}$ agonists have a presynaptic action to release glutamate from afferents with a restricted laminar expression (Aghajanian and Marek 1997). The majority of these afferents appear to originate in the medial thalamus (Marek and Gewirtz 1999). Recently, we have found that activation of metabotropic glutamate2/3 (mGlu2/3) receptors suppresses the $5-\mathrm{HT}_{2 \mathrm{~A}}$ receptor-mediated increase in excitatory postsynaptic potentials/currents (EPSPs/ EPSCs) in layer $\mathrm{V}$ medial prefrontal cortical pyramidal cells (Marek et al. 2000). Conversely, blockade of mGlu2/3 receptors by the mGlu2/3 antagonist LY341495 enhances the frequency and amplitude of 5-HT-induced EPSCs. This latter result suggests that endogenous glutamate, released by activation of $5-\mathrm{HT}_{2 \mathrm{~A}}$ receptors, tonically activates $m$ Glu $2 / 3$ receptors that function to decrease the frequency of 5-HT-induced EPSCs. Taken together, these results imply that $\mathrm{mGlu} 2 / 3$ receptors (likely $\mathrm{mGlu2}$, see Marek et al. (2000)) function as autoreceptors on thalamocortical terminals upon which $5-\mathrm{HT}_{2 \mathrm{~A}}$ receptor activation induces glutamate release.

These interactions between mGlu receptors and $5-\mathrm{HT}_{2 \mathrm{~A}}$ receptors are of interest from a clinical perspective. The therapeutic action of a number of "atypical" antidepressant drugs, which do not appreciably block monoamine uptake or monoamine oxidase, (e.g., mianserin, mirtazepine, nefazodone, trazodone) may be mediated, in part, via blockade of 5- $\mathrm{HT}_{2 \mathrm{~A}}$ receptors (de Boer 1996; Eison et al. 1990; Marek et al. 1992; Wander et al. 1986). Similarly, blockade of $5-\mathrm{HT}_{2 \mathrm{~A}}$ receptors is thought to contribute to the therapeutic action of "atypical" antipsychotics such as clozapine, olanzepine, and risperidone (Altar et al. 1986; Ceulemans et al. 1985; Meltzer 1999; Meltzer et al. 1989; Rasmussen and Aghajanian 1988). Conversely, as discussed above, the psychotomimetic effects of hallucinogenic drugs is believed to involve activation of $5-\mathrm{HT}_{2 \mathrm{~A}}$ receptors. Thus, the aim of the present study was to evaluate whether mGlu2/3 agonists and antagonists modulate DOI-induced head shakes in a similar manner as previously observed to 5-HT-induced EPSCs from pyramidal cells of the medial prefrontal cortex slice in vitro preparation.

\section{METHOD}

\section{Subjects}

Fifty-nine male Sprague-Dawley rats (180-280 g, Harlan, Indianapolis, IN) were housed in suspended stainless steel wire cages $(18 \times 36 \times 20 \mathrm{~cm})$ with $2-4$ rats occupying each cage. The colony room was maintained at $\sim 20^{\circ} \mathrm{C}$ and relative humidity $(60 \%)$. The room was illuminated 12 hours/day (7 A.M. -7 P.M.). All rats had free access to laboratory chow (Teklad 4\% Rat Diet) and water except during experimental sessions. Most animals were injected with a moderate dose of DOI $(1.25 \mathrm{mg} / \mathrm{kg}$, ip) multiple times but with at least one week between injections to minimize homologous receptor down-regulation. The principles of laboratory animal care (NIH publication No. 85-23, revised 1985) were followed.

\section{General Procedure}

All experiments were performed between 10 A.M. and 4 P.M. The animals were transferred to an individual clear polycarbonate cage $(43 \times 21.5 \times 20 \mathrm{~cm})$ with a sawdust covered floor. All animals were habituated to this environment for 15 minutes before receiving a saline injection $(1 \mathrm{ml} / \mathrm{kg}$, ip). They were then videotaped and observed for a 30-min period. One or two days later, the rats were reintroduced into this same environment for a 15 -min habituation period. The animals were then injected with either saline or 1-(2,5-dimethoxy-4-iodophenyl)-2-aminopropane (DOI; IP, $5 \mathrm{mg} / \mathrm{kg}$ ) 15 minutes following the initial injection of either vehicle or the mGlu agonist/antagonist.

\section{Behavioral Observation}

The animals were observed for 30 minutes following the DOI injection. The observation period began one minute following the DOI injection to allow for drug absorption. Head shake responses were counted in consecutive 5 -min periods. Forward locomotion was also scored (movement from one end to the other end of the cage was scored as one cross). Backward locomotion, rearing, flat body posture, forepaw treading, skin jerks, chewing, and sniffing were observed but were not scored.

\section{Statistical Analysis}

All data are expressed as the mean \pm SEM. The raw data were analyzed with a Wilcoxon matched pairs test (Statistica). Calculation of $\mathrm{ID}_{50}$ values were performed by non-linear curve fitting (Delta Graph) after expressing the data as percent suppression of the DOI-induced head shakes.

\section{Drugs}

(1-(2,5-Dimethoxy-4-iodophenyl)-2-aminopropane $\mathrm{HCl}$, (DOI) was purchased from RBI (Natick, MA). (1S,2S, 5R,6S)-2-aminobicyclo[3.1.0] hexane-2,6- dicarboxylate monohydrate (LY354740) and 2S-2-amino-2-(1S,2S-2carboxycycloprop-1-yl) -2 (xanthy-9-yl) propanoic acid (LY341495) were kindly provided by Drs. James A. Monn and Darryle D. Schoepp of the Lilly Research Lab- 
oratories (Indianapolis, IN). Doses were calculated on the basis of the salt forms. The drugs were dissolved in saline, neutralized to a $\mathrm{pH} \sim 7.4$, and injected IP in a volume of $1 \mathrm{ml} / \mathrm{kg}$ body weight.

\section{RESULTS}

\section{Dose-dependent Induction of Head Shakes by DOI}

Since a considerable variability exists in frequency of DOI-induced head shakes among individual rats, a within-subject analysis would provide a more sensitive measure of drug-induced changes. Therefore, we performed a preliminary dose-response curve and assessed the tolerance to repeated weekly injections of a near-maximal concentration of DOI. A low dose of DOI $(0.32 \mathrm{mg} / \mathrm{kg}, \mathrm{n}=8$; Figure 1) produced minimal head shakes while a 4 -fold higher dose $(1.25 \mathrm{mg} / \mathrm{kg})$ produced a near-maximal frequency of head shakes compared to the $5 \mathrm{mg} / \mathrm{kg}$ dose. These results are similar to more extensive dose-response curves previously conducted (Pranzatelli 1990; Schreiber et al. 1995).

Previous work has shown that a single acute moderate dose of DOI $(1 \mathrm{mg} / \mathrm{kg})$, unlike a large dose $(7 \mathrm{mg} /$ $\mathrm{kg}$ ), does not result in down-regulation of $5-\mathrm{HT}_{2 \mathrm{~A}}$ binding sites (Buckholtz et al. 1988). In contrast, repeated daily treatment with a moderate dose of DOI $(1 \mathrm{mg} / \mathrm{kg})$ does down-regulate $5-\mathrm{HT}_{2 \mathrm{~A}}$ binding sites (Buckholtz et al. 1988; McKenna et al. 1989). Therefore, we tested the frequency of head shakes in a group of rats administered DOI $(1.25 \mathrm{mg} / \mathrm{kg}$, ip) over four consecutive weeks with drug injections seven days apart. The DOI-

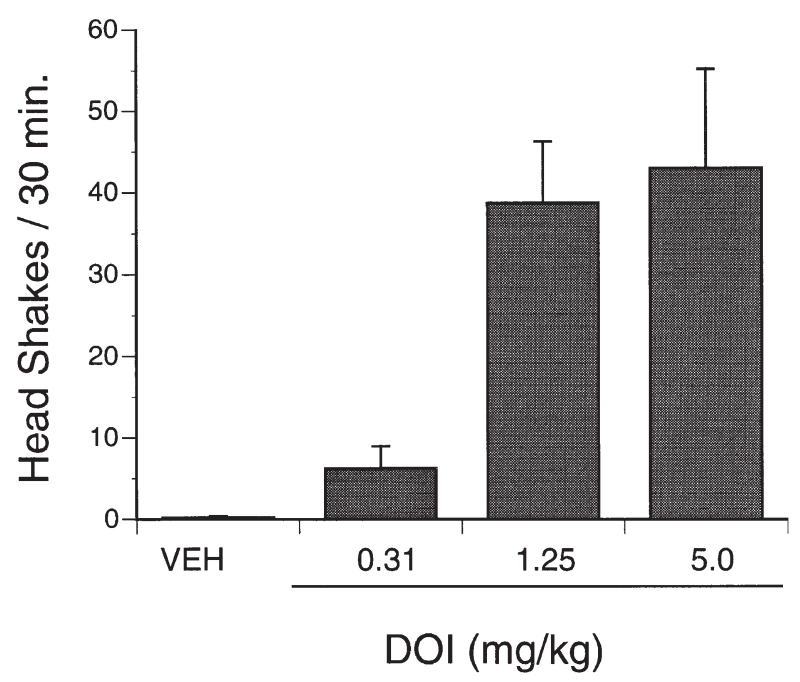

Figure 1. Dose-dependent increase in the frequency of DOI-induced head shakes. Rats were injected (ip; $1 \mathrm{ml} / \mathrm{kg}$ ) immediately prior to a $30 \mathrm{~min}$ observation period. Four rats received all three DOI doses at intervals of at least one week. An additional four rats were tested a single time with a single DOI dose. induced head shakes were non-significantly decreased during the fourth week to $86 \%$ of the frequency from the first week (Figure 2). DOI also induced a 4-5-fold increase in forward locomotion as assessed by longitudinal cage crosses. There was no change in forward locomotion as assessed by longitudinal cage crosses from week 1 to week 4 (not shown).

\section{The mGlu2/3 Agonist LY354740 Suppressed DOI-induced Head Shakes}

The selective mGlu2/3 agonist LY354740 (0.3-10 mg/ $\mathrm{kg}$, ip; Figure 3) suppressed the frequency of DOIinduced head shakes with an apparent $\mathrm{ED}_{50} \sim 1.1 \mathrm{mg} /$ $\mathrm{kg}$ and a maximal suppression of $\sim 60 \%$ at the $3 \mathrm{mg} / \mathrm{kg}$ dose. LY354740 did not significantly suppress the DOIinduced increase in forward locomotion, although a non-significant trend in this direction was present at the $3 \mathrm{mg} / \mathrm{kg}$ dose (not shown, $p=.13$ ). Similar to a previous report (Cartmell et al. 1999), we did not observe any behavioral effects of LY354740 (10 mg/ $\mathrm{kg}$, ip).

\section{The mGlu2/3 Antagonist LY341495 Enhances DOI-induced Head Shakes}

The efficacy of the selective mGlu2/3 antagonist LY341495 to enhance DOI-induced head shakes was tested using a dose of the drug $(1 \mathrm{mg} / \mathrm{kg})$ which has been found to effectively block the suppressant action of the mGlu2/3 agonists LY354740 and LY379268 on the motoric disruption induced by phencycline (Cart-

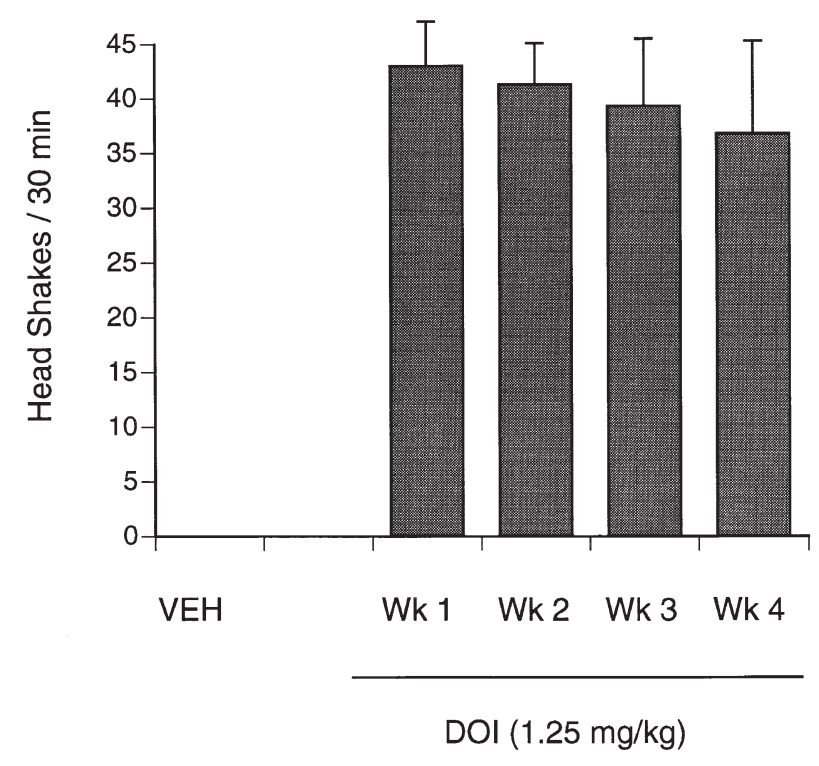

Figure 2. Effects of repeated weekly DOI-injections on the frequency of head shakes. The rats were injected with DOI $(1.25 \mathrm{mg} / \mathrm{kg}$; ip; $n=6)$ at weekly intervals. Note that there were no spontaneous head shakes when these rats were administered the vehicle injection. 


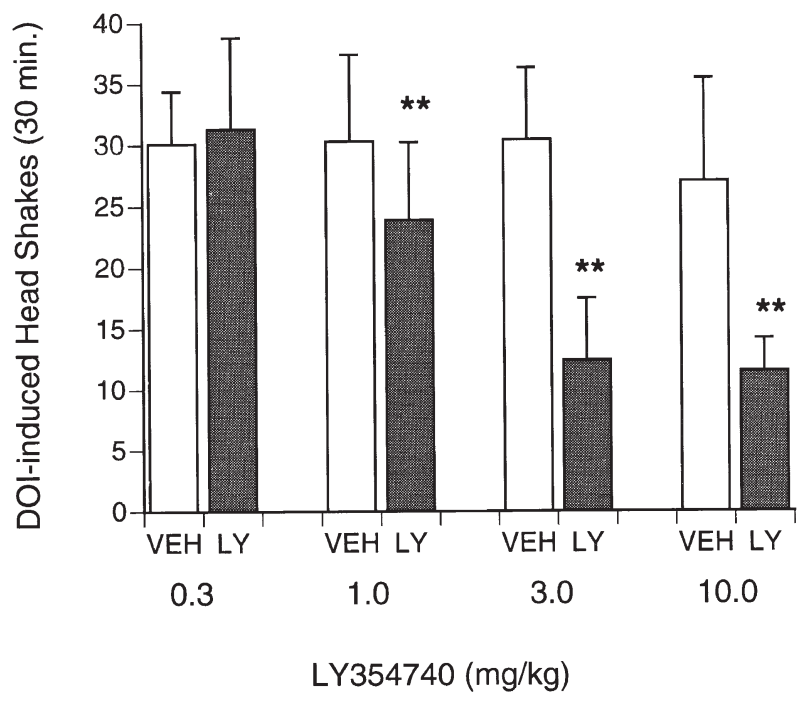

Figure 3. Dose-dependent suppression of the frequency of DOI-induced head shakes by the mGlu2/3 agonist LY354740 (0.3-10 mg/ $\mathrm{kg}$, ip). The open bars indicate the frequency of DOI-induced head shakes when separate groups ( $n=7$ for $0.3-3 \mathrm{mg} / \mathrm{kg} ; n=4$ for $10 \mathrm{mg} / \mathrm{kg}$ ) of rats were pretreated with the LY354740 vehicle. The closed bars indicate the frequency of DOI-induced head shakes during the 30 min observation period following pretreatment with varying doses of LY354740. ${ }^{* *} p<.01$, significantly different from respective control, Wilcoxon matched pairs test.

mell et al. 1999). We also found that LY341495 (1 mg/ $\mathrm{kg}$, ip), as reported previously (Cartmell et al. 1999), did not have any behavioral effects by itself. The present experiment involved an A-B-A design where DOI $(1.25 \mathrm{mg} /$ $\mathrm{kg}$ ) was administered three times with at least one week between injections and the mGlu2/3 antagonist was administered before DOI the second week. The head shake frequency with the combination of LY341945 and DOI was significantly increased to $150 \%$ of the value for the first week of DOI ( $p<.05$; Figure 4$)$ and was significantly increased to $161 \%$ of the value for the third week of DOI $(p<.01)$. While a trend was present for an increase in forward locomotion for the combination of LY341495 and DOI to $143 \%$ compared to the value for the first week of DOI $(p=.14)$, the combination did significantly increase forward locomotion to $188 \%(p<.05$; not shown) compared to the third week of DOI.

\section{DISCUSSION}

The first main finding from the present study is that activation of mGlu2/3 receptors by the highly selective mGlu2/3 agonist LY354740 (Monn et al. 1997; Schoepp et al. 1997) suppressed the frequency of DOI induced head shakes. The second main finding from the present study is that blockade of mGlu2/3 receptors by the se-

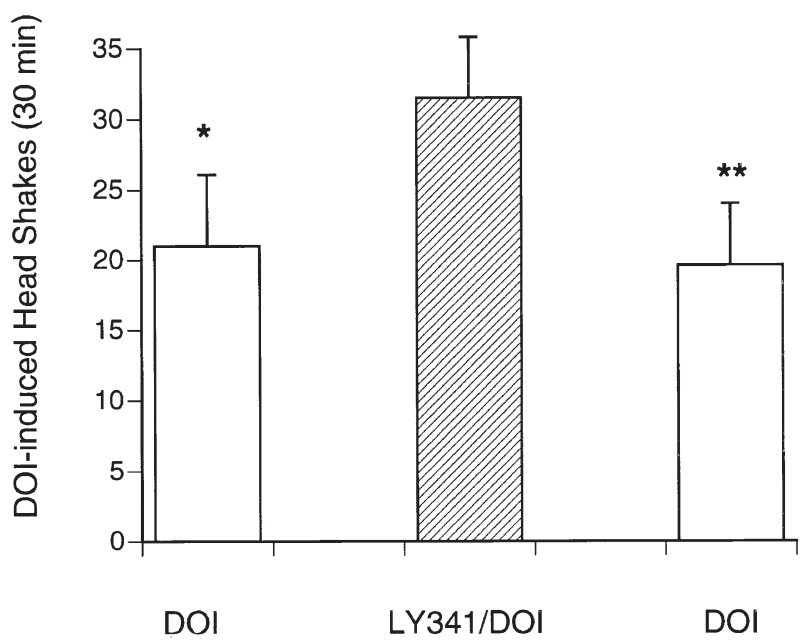

Figure 4. The mGlu2/3 antagonist LY341495 (1 mg/kg, ip; $n=12$ ) increases the frequency of DOI-induced head shakes. The open bars show the frequency of DOI-induced head shakes one week prior to and one week following pretreatment with LY341495. The hatched bar indicates the frequency of DOI-induced head shakes following pretreatment with LY341495. * $p<.05$, significantly different from the combination of DOI/LY341945. ${ }^{* *} p<.01$, significantly different from the combination of DOI/LY341495 using the Wilcoxon matched pairs test.

lective mGlu2/3 antagonist LY341495 (Kingston et al. 1998) enhanced the frequency of DOI-induced head shakes. These results are in complete accord with our recent report that selective mGlu2/3 agonists suppress, while the selective mGlu2/3 antagonist LY341495 enhances, the frequency and amplitude of synaptic currents/potentials induced by $5-\mathrm{HT}_{2 \mathrm{~A}}$ receptor activation from recordings of layer $\mathrm{V}$ pyramidal cells using an in vitro slice preparation of the medial prefrontal cortex. Taken together, these results suggest that a physiological interaction between $5-\mathrm{HT}_{2 \mathrm{~A}}$ and $\mathrm{mGlu} 2 / 3$ receptors exists with respect to DOI-induced head shakes.

While many of the rigid glutamate analogs such as the Lilly drugs used int he present work are highly selective for mGlu receptors compared to other metabotropic or glutamate ionotropic receptors owing to the relatively unique structure of mGlu receptors (Conn and Pin 1997), additional pharmacological interpretations of the present data are possible. First, the mGlu ligands used could be acting on novel mGlu receptors which have not been cloned or pharmacologically identified. Second, LY341945 appears to be only 3-7-fold selective at the mGlu2 vs. the mGlu8 receptor (Kingston et al. 1998). Thus, the enhancement of DOI-induced head shakes by this compound could be due to an interaction with mGlu8 receptors. However, in contrast to this slight selectivity of LY341495 for mGlu2 vs. mGlu8 receptors, the mGlu2/3 agonist LY354740 appears to be 120-1200-fold selective for mGlu2/3 than for mGlu8 
receptors (Monn et al. 1999). Thus, the most parsimonious explanation for the opposing effects of the mGlu2/ 3 agonist LY354740 and the mGlu2/3 antagonist LY341495 with respect to DOI-induced head shakes would be that either mGlu2 and/or mGlu3 modulates the effects of $5-\mathrm{HT}_{2 \mathrm{~A}}$ receptor activation by hallucinogenic phenethylamines.

The suppression and enhancement of DOI-induced head shakes by a mGlu2/3 agonist and a mGlu2/3 antagonist implicitly argues for a physiological interaction between $5-\mathrm{HT}_{2 \mathrm{~A}}$ receptors and glutamatergic neurotransmission. These results are in agreement with a recent report that both competitive and non-competitive NMDA antagonists enhance, while NMDA suppresses, the headtwitch response in mice induced by $5-\mathrm{HT}_{2 \mathrm{~A}}$ receptor activation (Kim et al. 1998). While the exact pathways by which this interaction occur have not been demonstrated, it is known that blockade of NMDA receptors increases glutamate release in the medial prefrontal cortex with a resulting increase in AMPA receptor activation (Moghaddam et al. 1997; Moghaddam and Adams 1998). This increased AMPA receptor activation in the medial prefrontal cortex is thought to mediate, in part, the psychotomimetic effects of NMDA antagonists. We have recently reviewed evidence suggesting that the psychotomimetic effects of both hallucinogens and non-competitive NMDA antagonists may result from a hyperglutamatergic state in the prefrontal cortex in both rodents and humans (Aghajanian and Marek 1999).

The present findings are consistent with the hypothesis that the primary action of the mGlu2/3 agonist LY354740, as an autoreceptor agonist, is to suppress pathologically enhanced glutamate release (Schoepp et al. 1999). Previous studies have found that LY354740 (10 mg/ $\mathrm{kg}$, ip) does not alter basal efflux of glutamate in the striatum or medial prefrontal cortex, but does block the increased glutamate release induced by veratridine or phencyclidine (Battaglia et al. 1997; Moghaddam and Adams 1998). In our electrophysiological studies of prefrontal pyramidal cells, LY354740 appeared to preferentially suppress the frequency of 5-HT-induced EPSCs while having no action on basal EPSC amplitude or frequency (Marek et al. 2000).

The locus of the $5-\mathrm{HT}_{2 \mathrm{~A}}$ and $\mathrm{mGlu} 2 / 3$ receptor physiological interaction with respect to DOI-induced head shakes is not known given the systemic route of administration for all drugs in the present study. However, $5-\mathrm{HT}_{2}$ agonists appear to induce head shakes both subcortically (Bedard and Pycock 1977; Lucki and Minugh-Purvis 1987) and in the medial prefrontal cortex (Granhoff et al. 1992b; Willins and Meltzer 1997). The localization of 5- HT $2 \mathrm{~A}$ receptors in the brain is consistent with both subcortical and cortical sites for the induction of head shake responses by hallucinogenic drugs. The $5-\mathrm{HT}_{2 \mathrm{~A}}$ receptor generally has a restricted expression at subcortical sites, but is strongly expressed in cranial and spinal motoneurons (Pompeiano et al. 1994; Wright et al. 1995). Certainly, one of the highest densities of $5-\mathrm{HT}_{2 \mathrm{~A}}$ receptors found in the brain is in layer $\mathrm{V}$ of the neocortex and medial prefrontal cortex (Blue et al. 1988; Lopez-Gimenez et al. 1997). With respect to the present behavioral results, the striking laminar correlation between the peak density of $\left[{ }^{125} \mathrm{I}\right] \mathrm{DOI}$ and $\left[{ }^{3} \mathrm{H}\right] \mathrm{LY} 354740$ binding sites in the midlayer of the rat medial prefrontal cortex (Marek et al. 2000 ) is of great interest. The peak densities of $5-\mathrm{HT}_{2 \mathrm{~A}}$ and mGlu2/3 binding appear to coincide with the terminal arborizations of the midline and intralaminar thalamic nuclei (Berendse and Groenewegen 1991; Blue et al. 1988). We also have recently reported that with recordings from layer $\mathrm{V}$ pyramidal cells of the medial prefrontal cortex that medial thalamic lesions decrease the frequency of 5-HT-induced EPSCs by $\sim 60 \%$ (Marek and Gewirtz 1999). Both the 5- $\mathrm{HT}_{2 \mathrm{~A}}$ and the mGlu2, but not the mGlu3, receptors appear to be expressed within the midline and thalamic intralaminar thalamic nuclei (Ohishi et al. 1993a; Ohishi et al. 1993b; Raghupathi et al. 1996). Thus, it is tempting to speculate that the behavioral interaction between $5-\mathrm{HT}_{2 \mathrm{~A}}$ and $\mathrm{mGlu} 2 / 3$ receptors demonstrated here may reflect modulation of thalamocortical terminals. However, local administration, rather than systemic administration of DOI and the mGlu agonists/antagonists will be required to demonstrate that the critical site of interaction between 5$\mathrm{HT}_{2 \mathrm{~A}}$ and mGlu2/3 receptors with respect to DOI-induced head shakes is in the medial prefrontal cortex.

Interestingly, LY354740 did not appear to completely suppress DOI-induced head shakes. MGlu2 receptors have a prominent expression in forebrain areas but have a relative weak expression in the cerebellum, lower brainstem and spinal cord (Ohishi et al. 1997; Ohishi et al. 1993a). Thus, mGlu agonists might not be able to suppress DOI-induced head shakes that are mediated through circuits independent of the prefrontal cortex involving subcortical pathways.

Clinical interest in these findings stems from the suggestion that the psychotomimetic effects of hallucinogenic drugs are mediated via activation of $5-\mathrm{HT}_{2 \mathrm{~A}}$ receptors (Glennon 1990), whereas the thymoleptic action of atypical antidepressant drugs (Marek et al. 1992) and atypical antipsychotic drugs (Meltzer 1999) may, in part, involve blockade of 5- $\mathrm{HT}_{2 \mathrm{~A}}$ receptors. In fact, the potency and efficacy of the $\mathrm{D}_{2} / 5-\mathrm{HT}_{2 \mathrm{~A}}$ antagonist pirenpirone in blocking the behavioral effects of LSD in rodents led to the clinical development of the atypical antipsychotic drug risperidone (Colpaert and Janssen 1983; Colpaert et al. 1982; Janssen et al. 1988). One strategy for novel drug design in the treatment of mood and psychotic disorders might be to investigate other transmitter systems which modulate the behavioral effects of hallucinogens in rodents. In this context it is interesting to note that previous studies have found that $5-\mathrm{HT}_{1 \mathrm{~A}}$ 
agonists (Arnt and Hyttel 1989; Darmani et al. 1990; Schreiber et al. 1995; Willins and Meltzer 1997), nicotine (Tizabi et al. 1999), and $\mu$-opioid agonists (Alvaro et al. 1998; Corne et al. 1963; Vetulani et al. 1980) suppress head shakes in rodents induced by $5-\mathrm{HT}_{2 \mathrm{~A}}$ agonists. Agonists for 5- $\mathrm{HT}_{1 \mathrm{~A}}$ (Amsterdam 1992; Haddjeri et al. 1998; Meltzer 1999; Newman-Tancredi et al. 1998; Wilcox et al. 1996), nicotine (Adler et al. 1998; Covey et al. 1997), and $\mu$-opioid (Bodkin et al. 1995; Carlson and Simpson 1963; Comfort 1977; Gold et al. 1977; O'Brien et al. 1984) receptors are suspected to play a role in the treatment and/or pathophysiology of both depression and schizophrenia. The present findings are consistent with previous reports that group II mGlu agonists may have therapeutic effects in the treatment of schizophrenia (Cartmell et al. 1999; Moghaddam and Adams 1998). In addition, the suppression by group II mGlu agonists of responses mediated by $5-\mathrm{HT}_{2 \mathrm{~A}}$ receptor activation also suggests these mGlu agonists may have antidepressant properties. Thus, understanding the locus and mechanism of physiological and behavioral interactions between $5-\mathrm{HT}_{2 \mathrm{~A}}$ and mGlu receptors may be of considerable heuristic value.

\section{ACKNOWLEDGMENTS}

Supported by PHS Grants K08 MH01551, a NARSAD Young Investigator Award (1999 Fairfax Investigator Award), and the State of Connecticut (G.J.M.). We thank Drs. Darryle Schoepp and James Monn for valuable discussions. We appreciate Dr. Younglim Lee's review of this manuscript. We thank Nigel Henry, Sara Heron, Andrew Kwak, Megan Lennon, and Boting Zhang for technical assistance. We also thank Leslie Rosello for secretarial assistance.

\section{REFERENCES}

Adler LE, Olincy A, Waldo M, Harris JG, Griffith J, Stevens K, Flach K, Nagamoto H, Bickford P, Leonard S, Freedman R (1998): Schizophrenia, sensory gating, and nicotinic receptors. Schizophrenia Bull 24:189-202

Aghajanian GK, Marek GJ (1997): Serotonin induces excitatory postsynaptic potentials in apical dendrites of neocortical pyramidal cells. Neuropharmacology 36:589599

Aghajanian GK, Marek GJ (1999): Serotonin-glutamate interactions: a new target for antipsychotic drugs. Neuropsychopharmacol 21:S122-S133

Altar CA, Wasley AM, Neale RF, Stone GA (1986): Typical and atypical antipsychotic occupancy of D2 and S2 receptors: An autoradiographic analysis in rat brain. Brain Res Bull 16:517-525

Alvaro JD, Aghajanian GK, Marek GJ (1998): $\mu$-Opiate agonists block head shakes induced by the serotonin ${ }_{2 \mathrm{~A}}$ agonist DOI. Soc Neurosci Abstr 24:1369

Amsterdam JD (1992): Gepirone, a selective serotonin (5-
$\mathrm{HT}_{1}$ ) partial agonist in the treatment of major depression. Prog Neuro-Psychopharmacol \& Biol-Psychiat $16: 271-280$

Arnt J, Hyttel J (1989): Facilitation of 8-OHDPAT-induced forepaw treading of rats by the 5-HT2 agonist DOI. European Journal of Pharmacology 161:45-51

Battaglia G, Monn JA, Schoepp DD (1997): In vivo inhibition of veratridine-induced release of excitatory amino acids by the group II metabotropic agonist LY354740 in rats. Neurosci Lett 229:161-164

Bedard P, Pycock CJ (1977): 'Wet-dog' shake behaviour in the rat: a possible quantitative model of central 5-hydroxytryptamine activity. Neuropharmacology 16:663-670

Berendse HW, Groenewegen HJ (1991): Restricted cortical termination fields of the midline and intralaminar thalamic nuclei in the rat. Neuroscience 42:73-102

Blue ME, Yagaloff KA, Mamounas LA, Hartig PR, Molliver ME (1988): Correspondence between $5-\mathrm{HT}_{2}$ receptors and serotonergic axons in rat neocortex. Brain Res 453:315-328

Bodkin JA, Zornberg GL, Lukas SE, Cole JO (1995): Buprenorphine treatment of refractory depression. Journal of Clinical Psychopharmacology 15:49-57

Buckholtz NS, Zhou D, Freedman DX (1988): Serotonin ${ }_{2}$ agonist administration down-regulates rat brain serotonin ${ }_{2}$ receptors. Life Sciences 42:2439-2445

Carlson ET, Simpson MM (1963): Opium as a tranquilizer. American Journal of Psychiatry 120:112-117

Cartmell J, Monn JA, Schoepp DD (1999): The mGlu2/3 receptor agonists, LY354740 and LY379268, selectively attenuate phencyclidine versus d-amphetamine motor behavior in rats. J Pharmacol Exp Ther 291:161-170

Ceulemans DLS, Gelders YG, Hoppenbrouwers M-LJA, Reyntjens AJM, Janssen PAJ (1985): Effect of serotonin antagonism in schizophrenia: A pilot study with setoperone. Psychopharmacol 85:329-332

Colpaert FC, Janssen PAJ (1983): The head-twitch response to intraperitoneal injection of 5-hydroxytryptophan in the rat: antagonist effects of purported 5-hydroxytryptamine antagonists and of pirenperone, an LSD antagonist. Neuropharmacol 22:993-1000

Colpaert FC, Niemegeers CJE, Janssen PAJ (1982): A drug discrimination analysis of lysergic acid diethylamide (LSD): In vivo agonist and antagonist effects of purported 5-hydroxytryptamine antagonists and of pirenperone, a LSD-antagonist. J Pharmacol Exp Ther 221:206-214

Comfort A (1977): Morphine as an antipsychotic? Clinical Toxicology 11:383-386

Conn PJ, Pin J-P (1997): Pharmacology and functions of metabotropic glutamate receptors. Annu Rev Pharmacol Toxicol 37:205-237

Corne SJ, Pickering RW, Warner BT (1963): A method for assessing the effects of drugs on the central actions of 5-hydroxytryptamine. Br J Pharmacol 20:106-120

Covey LS, Glassman AH, Stetner F (1997): Major depression following smoking cessation. Am J Psychiatry 154:263-265

Darmani NA, Martin BR, Pandey U, Glennon RA (1990): Do functional relationships exist between $5-\mathrm{HT}_{1 \mathrm{~A}}$ and $5-\mathrm{HT}_{2}$ receptors? Pharmacol. Behav Biochem 36:901-906 
de Boer T (1996): The pharmacologic profile of mirtazepine. Journal of Clinical Psychiatry 57:19-25

Eison AS, Eison MS, Torrente JR, Wright RN, Yocca FD (1990): Nefazodone: preclinical pharmacology of a new antidepressant. Psychopharmacology Bulletin 26:311-315

Gingrich JA, Zhou M, Sealfon S, Hen R (1999): Mice lacking the $5-\mathrm{HT}_{2 \mathrm{~A}}$ receptor are insensitive to many of the behavioral and physiological effects of hallucinogens. Soc Neurosci Abstr 25:799

Glennon RA (1990): Do classical hallucinogens act as 5- $\mathrm{HT}_{2}$ agonists or antagonists? Neuropsychopharmacol 3:509517

Gold MS, Donabedian RK, Dillard M, Slobetz FW, Riordan CE, Kleber HD (1977): Antipsychotic effect of opiate agonists. The Lancet 2:398-399

Granhoff MI, Lee L, Jackson A, Patel K, Martinez Y, Ashby CR, Wang RY (1992a): The interaction of 5-HT1A and 5HT2 receptors in the medial prefrontal cortex: Behavioral studies. Society for Neurosciences (Abstract) 18:1380

Granhoff MI, Lee L, Jackson A, Patel K, Martinez Y, Ashby CR, Wang RY (1992b): The interaction of $5-\mathrm{HT}_{1 \mathrm{~A}}$ and $5-\mathrm{HT}_{2}$ receptors in the medial prefrontal cortex: Behavioral studies. Soc Neurosci (Abstr) 18:1380

Gudelsky GA, Koenig JI, Meltzer HY (1986): Thermoregulatory responses to serotonin (5-HT) receptor stimulation in the rat. Evidence for opposing roles of $5-\mathrm{HT}_{2}$ and $5-\mathrm{HT}_{1 \mathrm{~A}}$ receptors. Neuropharmacol 25:1307-1313

Haddjeri N, Blier P, deMontigny C (1998): Long-term antidepressant treatments result in a tonic activation of forebrain 5- $\mathrm{HT}_{1 \mathrm{~A}}$ receptors. J Neurosci 18:10150-10156

Jakab RL, Goldman-Rakic PS (1998): 5-HT2A serotonin receptors in the primate cerebral cortex: Possible site of action of hallucinogens in pyramidal cell apical dendrites. Proc Natl Acad Sci USA 95:735-740

Janssen PAJ, Niemegeers CJE, Awouters F, Schellenkens KHL, Megens AAHP, Meert TF (1988): Pharmacology of risperidone ( $\mathrm{R} 64$ 766):, a new antipsychotic with serotonin- $S_{2}$ and dopamine- $\mathrm{D}_{2}$ antagonistic properties. J Pharmacol Exp Ther 244:685-693

Kim H-S, Park I-S, Park W-K (1998): NMDA receptor an tagonists enhance 5- $\mathrm{HT}_{2}$ receptor-mediated behavior, head-twitch response, in mice. Life Sci 63:2305-2311

Kingston AE, Ornstein PL, Wright RA, Johnson BG, Mayne NG, Burnett JP, Belagaje R, Wu S, Schoepp DD (1998): LY341495 is a nanomolar potent and selective antagonist of group II metabotropic glutamate receptors. Neuropharmacology 37:1-12

Lopez-Gimenez JF, Mengod G, Palacios JM, Vilaro MT (1997): Selective visualization of rat brain 5-HT2A receptors by autoradiography with [3H]MDL 100,907. Naunyn-Schmiedeberg's Arch Pharmacol 356:446-454

Lucki I, Minugh-Purvis N (1987): Serotonin-induced head shaking behavior in rats does not involve receptors located in the frontal cortex. Brain Res. 420:403-406

Lucki I, Nobler MS, Frazer A (1984): Differential actions of serotonin antagonists on two behavioral models of serotonin receptor activation in the rat. J Pharmacol Exp Ther 228:133-139

Marek GJ, Aghajanian GK (1996): LSD and the phenethylamine hallucinogen DOI are potent partial agonists at
5- $\mathrm{HT}_{2 \mathrm{~A}}$ receptors on neurons in the rat piriform cortex. $\mathrm{J}$ Pharmacol Exp Ther 278:1373-1382

Marek GJ, Gewirtz JC (1999): Serotonin ${ }_{2 A}$ receptor-induced EPSCs in layer $\mathrm{V}$ pyramidal cells of prefrontal cortex: block by lesions of medial thalamus. Soc for Neurosci Abstr 25:449

Marek GJ, McDougle CJ, Price LH, Seiden LS (1992): A comparison of trazodone and fluoxetine: implications for a serotonergic mechanism of antidepressant action. Psychopharmacol 109:2-11

Marek GJ, Wright RA, Schoepp DD, Monn JA, Aghajanian GK (2000): Physiological antagonism between 5-hydroxytryptamine $_{2 \mathrm{~A}}$ and group II metabotropic glutamate receptors in prefrontal cortex. J Pharmacol Exp Ther 292:76-87

McKenna DJ, Nazarali AJ, Himeno A, Saavedra JM (1989): Chronic treatment with $( \pm) \mathrm{DOI}$, a psychotomimetic $5-\mathrm{HT}_{2}$ agonists downregulates $5-\mathrm{HT}_{2}$ receptors in rat brain. Neuropsychopharmacol 2:81-87

Meltzer HY (1999): The role of serotonin in antipsychotic drug action. Neuropsychopharmacol 21:106S-115S

Meltzer HY, Matsubara S, Lee J-C (1989): Classification of typical and atypical antipsychotic drugs on the basis of dopamine D-1, D-2 and serotonin ${ }_{2} \mathrm{pK}_{\mathrm{i}}$ values. J Pharmacol Exp Ther 251:238-246

Moghaddam B, Adams B, Verma A, Daly D (1997): Activation of glutamatergic neurotransmission by ketamine: A novel step in the pathway from the NMDA receptor blockade to dopaminergic and cognitive disruptions associated with the prefrontal cortex. J Neurosci 17:2921-2927

Moghaddam B, Adams BW (1998): Reversal of phencyclidine effects by a group II metabotropic glutamate receptor agonists in rats. Science 281:1349-1352

Monn JA, Valli MJ, Massey SM, Hansen MM, Kress TJ, Wepsiec JP, Harkness AR, Grutsch JL, Wright RA, Johnson BG, Andis SL, Kingston A, Tomlinson R, Lewis R, Griffey KR, Tizzano JP, Schoepp DD (1999): Synthesis, pharmacological characterization, and molecular modeling of heterobicyclic amino acids related to (+)-2-aminobicyclo[3.1.0]hexane-2,6-dicarboxylic acid (LY354740): Identification of two new potent, selective and systemically active agonists for group II metabotropic glutamate receptors. J Med Chem 42:1027-1040

Monn JA, Valli MJ, Massey SM, Wright RA, Salhoff CR, Johnson BG, Howe T, Alt CA, Rhodes GA, Robey RL, Griffey KR, Tizzano JP, Kallman MJ, Helton DR, Schoepp DD (1997): Design, synthesis, and pharmacological characterization of (+)-2-aminobicyclo[3.1.0]hexane-2,6dicarboxylic acid (LY354740): A potent, selective, and orally active group 2 metabotropic glutamate receptor agonist possessing anticonvulsant and anxiolytic properties. J Med Chem 40:528-537

Newman-Tancredi A, Gavaudan S, Conte C, Chaput C, Touzard M, Verriele L, Audinot V, Millan MJ (1998): Agonist and antagonist actions of antipsychotic agents at 5-HT1A receptors: a $\left[{ }^{35} \mathrm{~S}\right] \mathrm{GTP} \gamma \mathrm{S}$ binding study. Eur J Pharmacol 355:245-256

O'Brien CP, Woody GE, McLellan AT (1984): Psychiatric disorders in opioid-dependent patients. Journal of Clinical Psychiatry 45:9-13

Ohishi H, Neki A, Mizuno N (1997): Distribution of a 
metabotropic glutamate receptor, mGluR2, in the central nervous system of the rat and mouse: an immunohistochemical study with a monoclonal antibody. Neuroscience Res 30:65-82

Ohishi H, Shigemoto R, Nakanishi S, Mizuno N (1993a): Distribution of the messenger RNA for a metabotropic glutamate receptor, mGluR2, in the central nervous system of the rat. Neuroscience 53:1009-1018

Ohishi H, Shigemoto R, Nakanishi S, Mizuno N (1993b): Distribution of the mRNA for a metabotropic glutamate receptor (mGluR3) in the rat brain: an in situ hybridization study. J Comp Neurol 335:252-266

Peroutka SJ, Lebovitz RM, Snyder SH (1981): Two distinct central serotonin receptors with different physiological function. Science 212:827-829

Pompeiano M, Palacios JM, Mengod G (1994): Distribution of the serotonin $5-\mathrm{HT}_{2}$ receptor family mRNAs: comparison between $5-\mathrm{HT}_{2 \mathrm{~A}}$ and $5-\mathrm{HT}_{2 \mathrm{C}}$ receptors. Mol Brain Res 23:163-178

Pranzatelli MR (1990): Evidence for involvement of 5- $\mathrm{HT}_{2}$ and $5-\mathrm{HT}_{1 \mathrm{C}}$ receptors in the behavioral effects of the 5 - $\mathrm{HT}$ agonist 1-(2,5-dimethoxy-4-iodophenyl aminopropane)2 (DOI). Neurosci Lett 115:74-80

Raghupathi RK, Artymyshyn R, McGonigle P (1996): Regional variability in changes in $5-\mathrm{HT}_{2 \mathrm{~A}}$ receptor mRNA levels in rat brain following irreversible inactivation with EEDQ. Mol Brain Res 39:198-206

Rasmussen K, Aghajanian GK (1988): Potency of antipsychotics in reversing the effects of a hallucinogenic drug on locus coeruleus neurons correlates with $5-\mathrm{HT}_{2}$ binding affinity. Neuropsychopharmacology 1:101-107

Schoepp DD, Johnson BG, Wright RA, Salhoff CR, Mayne NG, Wu S, Cockerham SL, Burnett JP, Belagaje R, Bleakman D, Monn JA (1997): LY354740 is a potent and highly selective group II metabotropic glutamate receptor agonist in cells expressing human glutamate receptors. Neuropharmacology 36:1-11

Schoepp DD, Monn JA, Marek GJ, Aghajanian GK, Moghaddam B (1999): LY354740: A systemically active mGlu2/3 receptor agonist. CNS Drug Reviews 5:1-12

Schreiber R, Brocco M, Audinot V, Gobert A, Veiga S, Millan MJ (1995): (1-(2,5-Dimethoxy-4 iodophenyl)-2-aminopropane)-induced head-twitches in the rat are mediated by 5-hydroxytryptamine (5-HT)2A receptors: Modulation by novel 5-HT2A/2C antagonists, D1 antagonists and t-HT1A agonists. J Pharmacol Exp Ther 273:101-112

Titeler M, Lyon RA, Glennon RA (1988): Radioligand binding evidence implicates the brain $5-\mathrm{HT}_{2}$ receptor as a site of action for LSD and phenethylamine hallucinogens. Psychopharmacol 94:213-216

Tizabi Y, Russell LT, Johnson M, Darmani NA (1999): Headtwitch response induced by DOI is attenuated by nicotine pretreatment. Soc Neurosci Abstr 25:60

Vetulani J, Bednarczyk B, Reichenberg K, Rokosz A (1980): Head twitches induced by LSD and quipazine: similarities and differences. Neuropharmacol 19:155-158

Vollenweider FX, Vollenweider-Scherpenhuyzen MFI, Babler A, Vogel H, Hell D (1998): Psilocybin induces schizophrenia-like psychosis in humans via a serotonin2 agonist action. NeuroReport 9:3897-3902

Wander TJ, Nelson A, Okazaki H, Richelson E (1986): Antagonism by antidepressants of serotonin $S_{1}$ and $S_{2}$ receptors of normal human brain in vitro. Eur J Pharmacol 132:115-121

Wilcox CS, Ferguson JM, Dale JL, Heiser JF (1996): A doubleblind trial of low- and high-dose ranges of gepirone-ER compared with placebo in the treatment of depressed outpatients. Psychopharmacol Bull 32:335-342

Willins DL, Deutch AY, Roth BL (1997): Serotonin 5-HT2A receptors are expressed on pyramidal cells and interneurons in the rat cortex. Synapse 27:79-82

Willins DL, Meltzer HY (1997): Direct injection of 5-HT2A receptor agonists into the medial prefrontal cortex produces a head-twitch response in rats. J Pharmacol Exp Ther 282:699-706

Wing LL, Tapson GS, Geyer MA (1990): 5-HT-2 mediation of acute behavioral effects of hallucinogens in rats. Psychopharmacol 100:417-425

Wright DE, Seroogy KB, Lundgren KH, Davis BM, Jennes L (1995): Comparative localization of $\operatorname{serotonin}_{1 \mathrm{~A}, 1 \mathrm{C}}$, and ${ }_{2}$ receptor subtype mRNAs in rat brain. J Comp Neurol 351:357-373

Yap CY, Taylor DA (1983): Involvement of 5- $\mathrm{HT}_{2}$ receptors in the wet-dog shake behaviour induced by 5 -hydroxtryptophan in the rat. Neuropharmacol 22:801-804 